\title{
Perspectives on Changes in the Right to Legal Assistance Prior to and During Police Interrogation
}

\author{
Willem-Jan Verhoeven*
}

The way in which the rights of suspects - equality of arms, privilege against self-incrimination, and the right to silence - can be guaranteed during criminal investigations has been discussed for decades. ${ }^{1}$ The discussion focuses mainly on the role of legal advisors during criminal investigations and the question whether they should be allowed to be present during police interrogation. Advocates of the right to legal assistance prior to and during police interrogation argue that access to a legal advisor is necessary to protect the autonomous legal position of suspects. Additionally, they argue that legal advisors can protect suspects against unlawful use of police pressure. ${ }^{2}$ Opponents of the right to legal assistance prior to and during police interrogation stress the importance of truth finding during the initial stages of criminal investigations. They suggest that early access to legal advisors, especially their presence during police interrogation, may interfere with the truth-finding process and degrade the usefulness of police interrogation for gathering evidence. ${ }^{3}$

In recent years, the right to legal assistance prior to and during police interrogation for suspects in police custody has seen several developments in the Netherlands (as well as in Europe as a whole). An experiment with a

* Erasmus School of Law, Department of Criminology, Erasmus University Rotterdam.

1. C.J.C.F. Fijnaut, De toelating van raadslieden tot het politiële verdachtenverhoor [The admission of counsel to police interrogations] (1987). C.J.C.F. Fijnaut, 'De toelating van de raadsman tot het politiële verdachtenverhoor. Een status questionis op de drempel van de eenentwintigste eeuw [The admission of counsel to police interrogation. A status quaestionis at the doorstep of the twenty-first century]', in M.S. Groenhuijsen and G. Knigge (eds.), Het vooronderzoek in strafzaken. Tweede interimrapport onderzoeksproject Strafvordering [The preliminary investigation in criminal cases. The second interim report in the research project Criminal proceedings] (2001) 671. T.N.B.M Spronken, Een onderzoek naar de normering van het optreden van advocaten in strafzaken [A study of the standardisation of the way lawyers act in criminal cases] (2001)

2. W.J. Verhoeven and L. Stevens, 'The Lawyer in the Dutch Interrogation Room: Influence on Police and Suspect', 9 Journal of Investigative Psychology and Offender Profiling 69 (2012).

3. M. Bockstaele, 'Verandering in verhoor- en onderzoekstechnieken ingevolge de "Salduzwet"' [Changing interrogation and investigation techniques in accordance with the "Salduzwet"], in P. Ponsaers, J. Terpstra, C. de Poot, M. Bockstaele \& L. Gunther Moor (eds.), Vernieuwing in de opsporing: een terreinverkenning [Innovation in criminal investigation: an exploration] (2013) 197. D. Dixon, 'Common sense, legal advice and the right of silence', Public Law 233 (1991). lawyer being present during police interrogations was carried out between 2008 and 2010 in the regions Amsterdam-Amstelland and Rotterdam-Rijnmond. The aim of the experiment was to determine whether the presence of a lawyer could contribute to making police interrogation more transparent and verifiable and to preventing the use of unlawful pressure. The study evaluating the experiment showed several interesting results. First, suspects who consulted a lawyer before the interrogation more often used their right to remain silent than suspects who did not consult a lawyer before the interrogation. Second, on average criminal investigators used more intimidation tactics when confronted with suspects who used their right to remain silent compared to suspects who talked. Third, during interrogations in the presence of a lawyer criminal investigators on average used less intimidation tactics compared to interrogations in the absence of a lawyer. These findings indicate that consultation prior to the interrogation should be followed up by assistance during the interrogation in order to safeguard suspects' rights and prevent improper coercion. ${ }^{4}$

Shortly after the start of the experiment, the European Court of Human Rights (ECtHR) issued a judgment in the case of Salduz v. Turkey and formulated the basic premise that suspects being questioned by the police must have access to some form of legal assistance. If legal assistance is not provided, any statement made by a suspect during police interrogation may not be used against him $/$ her. ${ }^{5}$ At that time, it was unclear whether a general right to legal assistance during police interrogation could be derived from this premise. ${ }^{6}$ Six months later, the Dutch Supreme Court (Hoge Raad) issued a ruling in three cases which, on the basis of the Salduz judgment by the ECtHR, resulted in appeals on ques-

4. L. Stevens and W.J. Verhoeven, Raadsman bij politieverhoor. Invloed van voorafgaande consultatie en aanwezigheid van raadslieden op de organisatie en wijze van verhoren en de proceshouding van verdachten [On the presence of legal advisers during police interrogations. Influence of prior consultation and presence of lawyers on the organisation and way of interrogating and on suspect's position] (2010).

5. Salduz v. Turkey, ECHR Grand Chamber (2008), No. 36391/02.

6. M.J. Borgers, 'Een nieuwe dageraad voor de raadsman bij het politieverhoor? [A new dawn for the counsel at the police interrogation]', 84 Nederlands Juristenblad 88 (2009). T. Spronken, 'Ja, de zon komt op voor de raadsman bij het politieverhoor! [Yes, the sun is rising for counsel at the police interrogation]', 84 Nederlands Juristenblad 94 (2009). 
tions of law being brought. ${ }^{7}$ This ruling made clear how the jurisprudence of the ECtHR regarding legal assistance must be interpreted in the Dutch criminal justice system. In essence, all suspects were given the right to consult with a lawyer prior to the interrogation, and juvenile suspects were given the right to have a lawyer or an appropriate adult present during the interrogation. These developments in legal assistance prior to and during police interrogation have resulted in the adaptation of regulatory instruments in the Netherlands ${ }^{8}$ and at the level of the European Union (EU). ${ }^{9}$

The requirement of legal assistance prior to and during police interrogation constitutes one of the major changes in Dutch criminal proceedings during the past years. Legislation, policy, and practice in the Netherlands have been adapted to European case law, including the $\mathrm{Sal}$ $d u z$ judgment, and the EU Directive, raising practical as well as fundamental questions about the implications of these developments. This issue of Erasmus Lam Reviem is devoted to these implications. The contributions to this issue address these developments and their consequences from 1) a Dutch national perspective, 2) a European comparative perspective, 3 ) a youth perspective, and 4) a psychological perspective.

The first contribution by Paul Mevis and Joost Verbaan deals with the Dutch response to the Salduz case and other relevant cases (collectively referred to as the ' $\mathrm{Sal}$ $d u z$ ' jurisprudence). Traditionally, the Netherlands has a somewhat restrained attitude towards the right to legal assistance prior to and during police interrogation. As a result, there was no thoroughly regulated system of legal assistance prior to, during, and after police interrogation to safeguard the rights of suspects in police custody. The Dutch criminal proceedings to a great extent relied on the professionalism of police officers and justice officials to act in the interests of suspects in police custody. The 'Salduz' jurisprudence made it necessary to amend regulations and practice in the Netherlands. In response to the rulings of the ECtHR, a draft Bill on legal assistance and police interrogation was presented to Parliament in 2011. After the publication of the EU Directive, a revised draft Bill was presented in 2013. In their contribution, Mevis and Verbaan address the question to what extent the Dutch response to the rulings of the ECtHR, as formalised in the two Dutch draft Bills, meets the standards set out in the EU Directive. In doing so, they give an elaborate description of the elements of the Dutch criminal procedure that have been affected by the 'Salduz' jurisprudence. From their comparison of the Dutch draft Bills with the EU Directive, they conclude that the second Dutch draft Bill

7. Dutch Supreme Court, 30 June 2009, ECLI:NL:HR:2009:BH3081.

8. Draft Bill of February 13, 2014, retrieved from: <www.rijksoverheid.nl/ nieuws/2014/02/13/recht-op-bijstand-van-raadsman-tijdens-politieverhoor.html>. A revised version of the draft Bill was published on April 15, 2011, retrieved from: <www.rijksoverheid.nl/documenten-en-publicaties/regelingen/2011/04/18/wetsvoorstel-rechtsbijstand-en-politieverhoor.html>

9. Directive 2013/48/EU of the European Parliament and of the Council of 22 October 2013, OJ 2013 L 294. leaves less room for interpretation compared to the first draft Bill. However, the reluctant tradition on legal assistance prior to and during interrogation under Dutch law might not fully support an open and effective interpretation of article 6 ECHR nor create an extensive practice on legal assistance.

The so-called 'Salduz' jurisprudence and the EU Directive on the right of access to a lawyer and the right to communicate with third persons has had consequences for the legislation on and the conduct of criminal proceedings of many Member States. Much can be learned from a comparative analysis between countries dealing with the 'Salduz' jurisprudence and the EU Directive. In the second contribution, Anna Ogorodova and Taru Spronken identify the practical factors that may influence the implementation of the EU Directive. Based on their legal (normative) analysis and empirical research, they focus on five particular aspects of the right to legal assistance, namely: 1) the conditions for waiver of the right, 2) the right of timely access to a lawyer, 3) the right to have a lawyer present at suspect interrogations, 4) the right to effective participation of a lawyer during interrogations of a suspect, and 5) the right to a lawyer of one's choice. From their comparative analysis of four European jurisdictions (England and Wales, France, the Netherlands, and Scotland), they conclude that further measures are still necessary to ensure proper implementation of the EU Directive in local police stations. The transposition of the EU Directive into the national laws of the Member States will require the development of complex nationwide programmes accompanied by organisational and policy measures and training of both criminal justice personal as well as the legal profession. Policy recommendations are given on the procedures to inform suspects about their right to legal advice and the right to waiver, on the procedures to organise timely access of a lawyer (of one's choice), and on the procedures to ensure lawyer's presence during police interrogation and clarify their role.

Criminal investigations, especially police interrogations, can have a severe impact particularly on juvenile suspects. ${ }^{10}$ Since the 'Salduz' jurisprudence, there seems to be a shared belief that special protection is needed for juvenile suspects during the stage of police interrogation. In the third contribution, Ton Liefaard and Yannick van den Brink propose that a youth-specific approach fundamentally different from the common approach for adults is required to ensure this special protection for juvenile suspects. However, there is ambivalence concerning the justifications and concrete implications of a youth-specific approach. Considering the implications of the insights from their interdisciplinary analysis, the authors address three core issues of the right to legal assistance for juvenile suspects in the context of the Dutch juvenile justice system. First, the

10. B.C. Feld, 'Police Interrogations of Juveniles: An Empirical Study of Policy and Practice', 97 Journal of Criminal Law and Criminology 219 (2006) 
Dutch approach not to give juveniles the possibility to waive their right to legal assistance seems a crucial prerequisite for safeguarding juveniles' right to a fair trial. However, in specific cases this may conflict with juveniles' right to personal liberty because it can take two hours (sometimes even longer) before a lawyer arrives at the police station. ${ }^{11}$ Second, lawyers are given a prominent role in providing adequate protection against (potential) fair trial violations and in enabling juveniles' effective participation in their trial. This complex task to act in the interests of a fair trial and in the interests of a pedagogically effective intervention, while taking into account the juvenile's best interest, requires specialised juvenile lawyers. Third, the decision of the Dutch legislator to favour legal assistance over other (e.g. parental) assistance seems questionable. Based on the aforementioned insights, Liefaard and Van den Brink argue that juveniles need more than only legal assistance, emotional support in particular. In conclusion, they position the right to legal assistance of juveniles in conflict with the Dutch juvenile justice system and they provide the Dutch legislator with concrete recommendations.

From the legal discussion, it follows that the justification of the right to legal assistance during the stage of police interrogation lies in two fundamental aspects of the right to a fair trial. Assistance of a lawyer is considered to be an important safeguard of the suspect's privilege against self-incrimination (his right to remain silent). Furthermore, the assistance of a lawyer is also meant to protect against coercion by the police. Miscarriages of justice that have come to light in the Netherlands ${ }^{12}$ as well as in other countries ${ }^{13}$ indicate that safeguarding these fundamental aspects of the right to a fair trial is necessary, since miscarriages of justice often originate from false confessions induced by police coercion. Therefore, extensive experimental research in psychology on the origins of false confessions can improve our understanding of the extent to which legal assistance may contribute to safeguarding the right to a fair trial. In the fourth contribution, Eric Rassin and Han Israels show that intuitively it appears unlikely that suspects act against

11. A. Ogorodova and T. Spronken, 'Legal Advice in Police Custody: From Europe to a Local Police Station', this issue Erasmus Law Review (2014). W.J. Verhoeven and L. Stevens, Rechtsbijstand bij politieverhoor. Evaluatie van de Aanwijzing rechtsbijstand politieverhoor in Amsterdam-Amstelland, Groningen, Haaglanden, Limburg-Zuid, Midden- en West-Brabant en Utrecht [Legal assistance at police interrogations. Evaluation of the Directive on legal counsel prior to and during police interrogations in Amsterdam-Amstelland, Groningen, Haaglanden, Middle and West Brabant, Utrecht, and South Limburg] (2013).

12. See e.g. P.J. van Koppen, 'Blundering Justice: The Schiedam Park Murder', in R.N. Kocsis (ed.), Serial Murder and the Psychology of Violent Crimes (2008) 207

13. See e.g. S.A. Drizin and R.A. Leo, 'The Problem of False Confessions in the Post-DNA World', 82 North Carolina Law Review 891 (2004). G.H. Gudjonsson, 'Unreliable Confessions and Miscarriages of Justice in Britain', 4 International Journal of Police Science and Management 332 (2002). S.M. Kassin, 'The Psychology of Confession Evidence', 52 American Psychologist 221 (1997). R.A. Leo and R.J. Ofshe, 'The Consequences of False Confessions: Deprivations of Liberty and Miscarriages of Justice in the Age of Psychological Interrogation', 88 Journal of Criminal Law and Criminology 429 (1998). their own interest and confess to a crime they did not commit. Thus, based on intuition, a confession seems a strong piece of evidence in criminal proceedings. However, findings from experimental studies in psychology show that innocent people are easily seduced to falsely confess a crime. This holds even more so for suspects in police custody who are isolated from the outside world. This situation may lead them to perceive confessing during an interrogation not as an act against their own best interest. Suspects may believe that confessing is the only fast and easy way out of the unpleasant and stressful situation of the police interrogation. Assistance of a lawyer during police interrogation (and videotaping as an alternative means) seems to alter police behaviour ${ }^{14}$ by reducing improper coercion and thus subsequently reducing false confessions. This conclusion underscores the importance of legal assistance during police interrogation for the purpose of safeguarding suspects' rights to a fair trial and ultimately preventing miscarriages of justice.

The contributions to this issue of Erasmus Lam Reviem deal with the consequences of the recent developments in the right to legal assistance during the initial stages of the criminal investigation from different disciplines. I approached specialists in criminal law and psychology to reflect on the topic of legal assistance prior to and during police interrogation in an attempt to illustrate the importance of an interdisciplinary approach to legal problems. I believe that the legal and empirical literature discussed in the four contributions provides an extensive overview of the research on the recent developments in the right to legal assistance during the initial stages of criminal investigations, its legal implications, and some practical implications. The legal contributions mainly focus on the question to what extent the Dutch draft Bill and the Dutch legal policy is in line with the Salduz jurisprudence, the EU directive, and the existing Dutch (juvenile) criminal justice system. However, as the contribution of Rassin and Israels, based on psychological research, shows, suspects make choices that may not seem logical or rational from a legal perspective. This raises the question to what extent the Dutch legislation and legal policy on the right to legal assistance at the police interrogation actually safeguards suspects' right to a fair trial. Are suspects in police custody in practice better suited to make choices in their best interest and to deal with the police interrogation now that there are more safeguards for their rights? To get more insight on this issue, I propose that future empirical studies should focus on the way suspects perceive coercion during interrogations, whether they desire more rights, understand their rights, and what they expect of legal assistance. Combining such empirical research with legal research focused on the perspective of the suspect improves our understanding of the

14. S.M. Kassin, J. Kukucka, V.Z. Lawson \& J. DeCarlo, 'Does Video Recording alter the Behavior of Police During Interrogation? A Mock Crime-and-Investigation Study', 38 Law and Human Behavior 73 (2014). Verhoeven and Stevens (2012), above n. 2. 
way legislation and legal policy (in this case on the right to legal assistance) may influence the behaviour of actors involved in the criminal justice system. ${ }^{15}$ This understanding may spur new developments in legislation and legal policy in order to make sure that the right to a fair trial remains 'practical and effective'. ${ }^{16}$

15. R.A. Leo, 'Inside the Interrogation Room', 86 The Journal of Criminal Law and Criminology 266 (1996).

16. Salduz v. Turkey, EHRM Grand Chamber (2008), No. 36391/02, r.o. 55. 